\title{
IMPLEMENTASI UU NO. 22 TAHUN 2009 YANG BERKAITAN DENGAN PENGGUNAAN HELM SNI DI KECAMATAN TEBAS
}

\author{
Yuliananingsih. $\mathbf{M}^{1}$, Fridino ${ }^{2}$ \\ ${ }^{1,2}$ Program Studi PPKN Fakultas Ilmu Pendidikan dan Pengetahuan Sosial IKIP PGRI Pontianak \\ Jalan Ampera Nomor 88 Pontianak - 78116, Telepon (0561) 748219 Fax. (0561) 6589855 \\ Email: myuliananingsih@gmail.com
}

\begin{abstract}
abstrak
Penelitian ini bertujuan untuk memperoleh informasi tentang implementasi UU No. 22 tahun 2009 yang berkaitan dengan penggunaan helm SNI di Kecamatan Tebas. Dari hasil penelitian ditetahui bahwa, aturan UU No. 22 tahun 2009 yang berkaitan dengan penggunaan helm SNI di Kecamatan Tebas sudah dilaksanakan dengan baik oleh pihak kepolisian dengan melakukan sosialisasi dan pemasang pamflet himbauan untuk menggunakan helm SNI saat berkendarna, serta memberikan sanksi berupa tilang apabila pengendara motor tidak menggunakan helm SNI dan atau tidak menggunakan helm sama sekali. Mengenai efektivitas pelaksanaan UU No. 22 tahun 2009 yang berkaitan dengan penggunaan helm SNI di Kecamatan Tebas kurang efektif, dikarenakan kurangnya peranan dan kesadaran dari masyarakat untuk mentaati dan menjalankan aturan tersebut, hal ini terlihat dari data pelanggaran helm standard yang setiap tahunnya semakin meningkat. Sedangkan faktor penghambat dalam implementasi UU No. 22 tahun 2009 yang berkaitan dengan penggunaan SNI meliputi faktor hukum, faktor penegak hukum, faktor sarana dan prasaran, faktor masyarakat dan faktor kebudayaan.
\end{abstract}

Kata Kunci: Implementasi, UU No 22 tahun 2009, Penggunaan, Helm SNI, Kecamatan Tebas.

\begin{abstract}
This study aims to obtain information about the implementation of Law No. 22 of 2009 relating to the use of SNI helmets in Tebas District. From the results of the study it was found that, the rules of Law No. 22 of 2009 relating to the use of SNI helmets in Tebas District has been implemented well by the police by conducting socialization and installing an appeal pamphlet to use SNI helmets while driving, as well as providing sanctions in the form of a ticket if motorcyclists do not use SNI helmets and or do not use helmets at all. Regarding the effectiveness of the implementation of Law No. 22 of 2009 relating to the use of SNI helmets in Tebas District is less effective, due to the lack of role and awareness of the public to obey and implement these rules, this can be seen from the data of standard helmet violations that are increasing every year. While inhibiting factors in the implementation of Law No. 22 of 2009 relating to the use of SNI include legal factors, law enforcement factors, facilities and infrastructure factors, community factors and cultural factors.
\end{abstract}

Keywords: Implementation, Law No. 22 of 2009, Use, SNI Helmet, Tebas District.

\section{PENDAHULUAN}

Transportasi adalah usaha memindahkan, mengerakan, mengangkut, atau mengalihkan suatu objek dari suatu tempat ke tempat lain, dimana di tempat lain ini objek tersebut lebih bermanfaat atau dapat berguna untuk tujuan tujuan tertentu Miro (2005). Menurut Soekanto (2006: 93) Ada lima unsur pokok transportasi, yaitu: a) manusia, yang membutuhkan tranportasi, b) barang yang diperlukan manusia, c) kendaraan, sebagai sarana, d) jalan, sebagai prasarana, dan e) organisasi, sebagai pengelola.

Transportasi berfungsi untuk mengatasi kesenjangan jarak dan komunikasi antara tempat asal dan tempat tujuan. Untuk itu dikembangkan sistem dalam wujud sarana (kendaraan) dan (prasarana jalan). Selain itu untuk menunjang sistem kelancaran transportasi tadi juga diperlukan sistem lalu lintas yang aman untuk berkendara. Demi menciptakan masyarakat yang aman dan tertib dalam berlalu lintas, pemerintah membuat suatu perundangan yaitu dalam bentuk Undang- 
Undang No. 22 tahun 2009 tentang Lalu Lintas Dan Angkutan Jalan (UU LLAJ). Perundangundangan merupakan syarat mutlak untuk menjamin adanya ketertiban dalam masyarakat. Menurut teori Hans Kelsen, bilamana tidak ada suatu undang-undang atau kebijakan, maka akan timbul kekacauan didalam masyarakat (Ashidiqqie (2012: 18)). Pemerintahan yang didukung oleh undang-undang dengan beraneka peraturan dan kebijakan ini beranggapan dapat menjamin berhasilnya mengatur warga negara.

Salah satu tugas utama warga negara adalah setiap warga negara wajib mentaati serta menjunjung tinggi dasar negara, hukum dan pemerintah tanpa terkecuali. Sebagai warga negara haruslah patuh dan taat pada undang-undang yang berlaku. Dimana undang-undanglah yang mengatur semua warga negara tanpa terkecuali. Salah satunya adalah UU LLAJ, terutama yang berkaitan dengan penggunaan helm Standar Nasional Indonesia (SNI)

Kementrian Perhubungan dalam liputan6 menyatakan helm merupakan perlindungan tubuh yang dikenakan dikepala dan biasanya terbuat dari metal atau bahan keras lainnya seperti kevlar, serat resin, atau plastik. Selanjutnya helm merupakan instrument keselamatan yang wajib dipenuhi oleh setiap pengemudi kendaraan bermotor roda dua, termasuk diantaranya adalah penumpang. Penggunaan helm yang memenuhi kualitas standar, agar keselamatan lebih terjamin apabila terjadi kecelakaan yang tidak dapat terelakkan. Lebih lanjut lagi dikatakan helm SNI adalah helm yang telah tersertifikasi kualitasnya oleh badan standarisasi yang ditunjuk oleh pemerintah dan telah memenuhi persyaratan material dan konstruksi, serta lolos berbagai pengujian.

Kewajiban menggunakan helm SNI bagi pengendara sepeda motor diatur dalam pasal 57 ayat (1) jo ayat (2) UU No. 22 Tahun 2009 Tentang Lalu Lintas dan Angkutan Jalan yang berbunyi:

(1) setiap kendaraan bermotor yang dioperasikan dijalan wajib dilengkapi dengan perlengkapan kendaraan bermotor,

(2) Perlengkapan sebagaimana dimaksud pada ayat (1) bagi sepeda motor berupa helm Standar Nasional Indonesia.

Berdasarkan data Satlantas Polres Sambas dari tahun 2015 sampai dengan 2017, pelanggaran yang terjadi pada tahun 2015 berjumlah 2.083 pelanggaran, tahun 2016 berjumlah 15.394 pelanggaran, dan tahun 2017 berjunlah 1.167 pelanggaran. Banyaknya kasus pelanggaran dijalan raya setidaknya mengambarkan cerminan kesadaran hukum masyarakat pengendara motor bahwa, masih banyak pengemudi sepeda motor di jalan yang tidak mengerti aturan lalu lintas. Selain itu kesadaran hukum masyarakat masih rendah sehingga membuat mereka cenderung tidak taat terhadap hukum. Hal tersebut terindekasikan dengan adanya pengendara yang tidak memakai helm yang SNI atau bahkan tidak menggunakan helm sama sekali. Bentuk pelanggaran ini sering

\section{JPKN}

Jurnal Pendidikan Kewarganegaraan
Implementasi Undang-Undang Nomor 22 Tahun 2009 Tentang Lalu Lintas dan Angkutan Jalan yang Berkaitan dengan Penggunaan Helm Standar Nasional Indonesia di Kecamatan Tebas Kabupaten Sambas 
dilakukan pada waktu tertentu dan dalam keadaan jalan yang sepi, sehingga sering terjadi kecelakaan yang mengakibatkan korban luka-luka dan atau meninggal dunia.

Berdasarkan uraian tersebut diatas yang menjadi yang menjadi masalah dalam penelitian ini adalah; (1) bagaimana aturan UU LLAJ yang berkaitan dengan penggunaan helm SNI di Kecamatan Tebas Kabupaten Sambas? (2) bagaimana efektivitas pelaksanaan UU LLAJ dengan penggunaan helm SNI oleh masyarakat di Kecamatan Tebas Kabupaten Sambas? (3) apa faktor penghambat implementasi UU LLAJ berkaitan dengan penggunaan helm SNI di Kecamatan Tebas Kabupaten Sambas?

\section{METODE}

Penelitian dilakukan dengan menggunakan metode kualitatif. Menurut Sugiyono (2014: 15), menjelaskan bahwa "metode penelitian kualitatif merupakan metode penelitan yang berlandaskan pada filsafat positivisme, digunakan untuk meneliti kondisi objek yang alamiah, dimana peneliti adalah sebagai instrumen kunci, pengambilan sampel sumber data dilakukan secara purposive dan snowball, dan hasil penelitian kualitatif lebih menekankan makna dari generalisasi”. Sedangkan bentuk penelitian yang digunakan dalam penelitian ini adalah bentuk yuridis empiris. Penelitian yuridis empiris adalah penelitian yang dilakukan dengan melihat kenyataan dilapangan terhadap kesesuaian dengan peraturan perundang-undangan. Menurut Soetandyo Wigyosoebroto dalam Zainuddin (2011: 30) mengatakan "penelitian yuridis adalah seluruh upaya untuk mencari dan menemukan jawaban yang benar (right answer) dan atau jawaban yang tidak sekali-kali keliru (true answer) mengenai suatu permasalahan”. Menurut beliau juga "untuk menjawab segala macam permasalahan hukum diperlukan hasil penelitian yang cermat, dan sahih untuk menjelaskan dan menjawab permasalahan yang ada". Teknik pengumpul data dalam penelitian ini adalah teknik observasi langsung, teknik komunikasi langsung, teknik studi dokumenter dan alat gumpul data dalam penelitian ini adalah panduan observasi, pedoman wawancara dan dokumentasi.

\section{HASIL DAN PEMBAHASAN}

Pada bagian ini peneliti akan menguraikan data dan hasil penelitian tentang permasalahan yang telah diuraikan sebelumnya. Hasil penelitian ini diperoleh dengan menggunakan sumber data dari informan untuk pencarian data dan pengumpulan dokumen yang berhubungan dengan implementasi UU LLAJ berkaitan dengan helm standar. Adapun yang menjadi informan dalam penelitian ini meliputi; Polisi Lalu Lintas Tebas, Kasat Lantas Polres Sambas, dan beberapa orang masyarakat Tebas.

\section{JPKN}

Jurnal Pendidikan Kewarganegaraan
Implementasi Undang-Undang Nomor 22 Tahun 2009 Tentang Lalu Lintas dan Angkutan Jalan yang Berkaitan dengan Penggunaan Helm Standar Nasional Indonesia di Kecamatan Tebas Kabupaten Sambas 
Pada bagian ini akan dideskripsikan mengenai paparan data penelitian yang berisi data hasil wawancara dan observasi dengan informasi (Polisi lalu lintas Tebas, Kasat lantas dan Masyarakat).

\section{Aturan Undang-undang No. 22 Tahun 2009 tentang Lalu Lintas dan Angkutan Jalan berkaitan dengan Penggunaan Helm Standar Nasional Indonesia di Kecamatan Tebas Kabupaten Sambas}

\section{Tabel 1}

\section{Matrik Hasil Temuan Aturan UU LLAJ Berkaitan Dengan Penggunaan Helm SNI}

\begin{tabular}{|c|c|}
\hline Hasil Wawancara & $\begin{array}{l}\text { Pihak kepolisian lalu lintas sudah baik dalam menerapkan } \\
\text { aturan LLAJ dengan melakukan sosialisasi ke desa-desa, ke } \\
\text { sekolah-sekolah dan juga memasang pamflet dijalan bahkan } \\
\text { apabila masyarakat atau pun pengendara motor tidak } \\
\text { menggunakan helm standar akan di tilang dan diberikan } \\
\text { sanksi. }\end{array}$ \\
\hline Hasil Obsevasi & $\begin{array}{l}\text { Penerapan UU LLAJ yang wajib menggunakan helm SNI } \\
\text { saat berkendara sepeda motor baik pengendara maupun } \\
\text { penumpangnya sepeda motor sudah disampaikan dan } \\
\text { diketahui oleh masyarakat, walaupun pun tidak dipungkiri } \\
\text { masih ada beberapa masyarakat yang tidak mentaati aturan } \\
\text { tersebut. }\end{array}$ \\
\hline Dokumentasi & $\begin{array}{l}\text { Dokumen yang dikumpulkan oleh peneliti seperti foto } \\
\text { tentang masyarakat khususnya pengendara motor dan } \\
\text { penumpang sepeda motor yang menggunakan helm SNI saat } \\
\text { berkendara. Dan pihak kepolisian lalu lintas melakukan } \\
\text { sosialisasi berupa pamflet himbauan apabila pengendara } \\
\text { motor yang tidak menggunakan helm SNI akan di tilang dan } \\
\text { diberikan sanksi. }\end{array}$ \\
\hline
\end{tabular}

Matrik diatas dapat disimpulkan bahwa aturan mengenai pengedara dan penumpang sepeda motor menggunakan helm SNI di Kecamatan Tebas sudah baik. Pihak kepolisian telah melakukan sosialisasi kepada masyarakat Kecamatan Tebas khususnya pengendara motor, seperti sosialisasi ke desa-desa, ke sekolah-sekolah, dan juga memasang pamflet himbauan untuk menggunakan helm SNI saat berkendara, serta memberikan sanksi berupa tilang apabila pengendara motor tidak menggunakan helm standar.

Berdasarkan analisi UU LLAJ pasal 108 ayat (8) mengatur bahwa: " Setiap orang yang mengemudikan sepeda motor dan penumpang sepeda motor wajib mengenakan helm yang memenuhi standar nasional". Apabila melanggar, ancaman atas pelanggaran tersebut diatur dalam Pasal 291 UU LLAJ:

(1) Setiap orang yang mengemudikan Sepeda Motor tidak mengenakan helm standar nasional Indonesia sebagaimana dimaksud dalam Pasal 106 ayat (8) dipidana dengan pidana kurungan 
paling lama 1 (satu) bulan atau denda paling banyak Rp.250.000,00 (dua ratus lima puluh ribu rupiah).

(2) Setiap orang yang mengemudikan Sepeda Motor yang membiarkan penumpangnya tidak mengenakan helm sebagaimana dimaksud dalam Pasal 106 ayat (8) dipidana dengan pidana kurungan paling lama 1 (satu) bulan atau denda paling banyak Rp. 250.000,00 (dua ratus lima puluh ribu rupiah).

Jadi pengguna kendaraan bermotor baik itu pengemudi maupun penumpang diwajibkan mengenakan helm SNI, sebagaimana yang diatur dalam UU LLAJ.

Efektivitas Pelaksanaan Undang-undang No. 22 Tahun 2009 tentang Lalu Lintas dan Angkutan Jalan berkaitan dengan Penggunaan Helm Standar Nasional Indonesia di Kecamatan Tebas Kabupaten Sambas

Tabel 2

Matrik Hasil Temuan Efektivitas pelaksanaan UU LLAJ Berkaitan Dengan Penggunaan Helm SNI

\begin{tabular}{ll}
\hline & Hasil wawancara dengan berbagai narasumber dapat \\
& disimpulkan bahwa Efektivitas pelaksanaan UULAJ \\
& berkaitan dengan penggunaan helm SNI masih kurang \\
efektif, karena masih banyak masyarakat khususnya & \\
pengendara motor maupun penumpang sepeda motor \\
tidak menggunakan helm SNI, hal ini disebabkan \\
kurangnya kesadaran masyarakat untuk mentaati atau \\
mematuhi peraturan tersebut.
\end{tabular}

Peneliti telah melakukan penelitian di Polsek Tebas dan di masyarakat. Berdasarkan hasil wawancara, obsevasi, dan dokumentasi bahwa efektivitas pelaksanaan UU LLAJ berkaitan dengan helm SNI kurang efektif.

Menurut Zainudin Ali (2006: 62) bahwa: "efektivitas hukum adalah daya kerja hukum dalam mengatur dan memaksa masyarakat untuk taat pada hukum”. Kurang efektifnya pelaksanaan UULAJ terkait penggunaan helm SNI dikarenakan kurangnya peranan dan kesadaran dari 
masyarakat dalam mentaati dan penjalankan aturan tersebut. Masyarakat seharusnya berperan penting dalam kelancaran, keamanan dan ketertiban, dan keselamatan berlalu-lintas, tapi pada kenyataannya merekalah yang cenderung lalai, acuh tak acuh, dan tidak mentaati tertib berlalulintas terutama dalam hal penggunaan helm SNI. Hal ini terlihat dari data kepolisian tentang pelanggaran lalu lintas penggunaan helm SNI dari tahun 2015 sampai 2017 adalah sebagai berikut;

Grafik

Jumlah Pelanggara Helm SNI

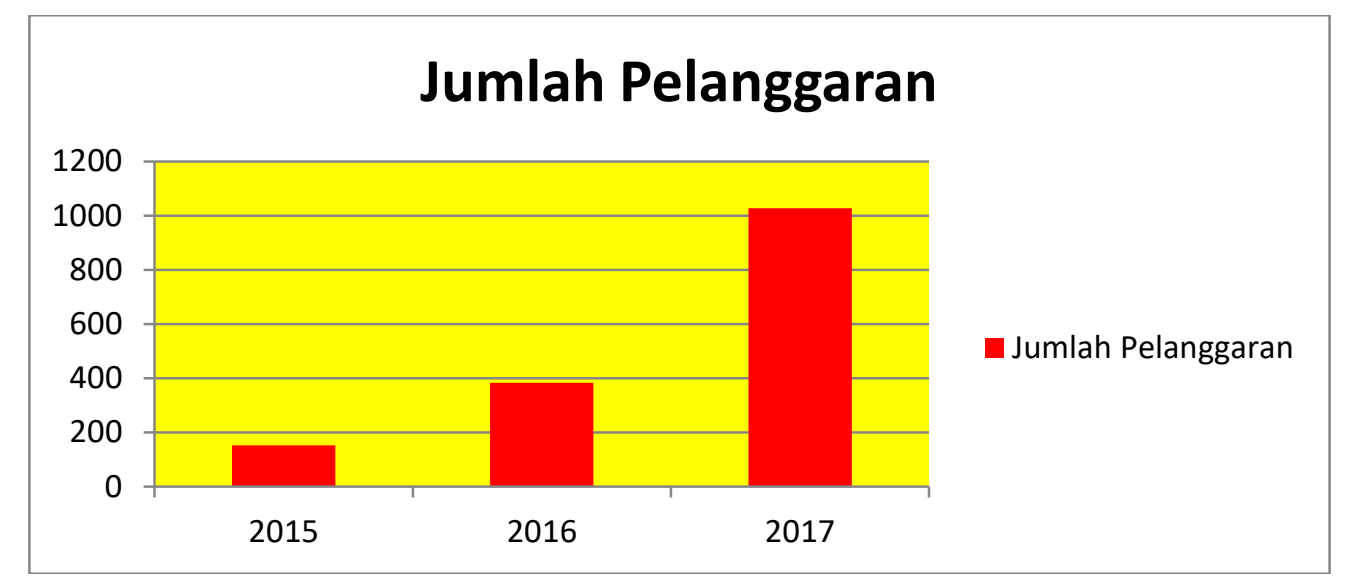

Sumber Data: Polsek Tebas

Melihat grafik diatas pelanggaran yang dilakukan masyarakat khususnya pengendara motor pengguna helm SNI setiap tahunnya mengalami peningkatan. Hal ini sangatlah mengkhawatirkan, sehingga perlu penanganan serius oleh pihak kepolisian untuk menyadarkan masyarakat taat pada UU LLAJ demi keselamatan mereka.

Faktor Penghambat Implementasi Undang-undang No. 22 Tahun 2009 tentang Lalu Lintas dan Angkutan Jalan berkaitan dengan Penggunaan Helm Standar Nasional Indonesia di Kecamatan Tebas Kabupaten Sambas

Setiap aturan undang undang yang diterapkan pasti banyak dipengaruhi hambatan,. Berikut hasil wawancara, obsevasi, dan dokumentasi mengenai hambatan-hambatan dalam menerapkan UU LLAJ berkaitan dengan penggunaan helm SNI. 
Tabel 4

Matrik Hasil Temuan Faktor Penghambat Implementasi UU LLAJ

\begin{tabular}{ll}
\hline & Hasil wawancara dengan berbagai informan dapat disimpulkan \\
& bahwa terdapat beberapa hambatan dalam penerapan UU LLAJ \\
& berkaitan dengan penggunaan helm SNI pada masyarakat Tebas, \\
& seperti; masih kurangnya kesadaran masyarakat pengendara yang \\
Berkaitan Dengan & tidak mentaati peraturan menggunakan helm SNI, dan juga budaya \\
Penggunaan Helm & masyarakat yang cendrung terbiasa tidak menggunakan helm SNI \\
SNI Hasil & dan atau tidak menggunakan helm sama sekali saat berpergian di \\
Wawancara & jarak yang dekat. Selain itu kurangnya personil penegak hukum \\
& untuk memantau dan mengawasi pengendara motor. Kurangnya \\
& sarana dan prasarana bagi pihak kepolisian menyebabkan pihak \\
& kepolisian kesulitan untuk melaksanakan penegakan aturan lalu \\
& lintas. \\
\hline Hambatan dalam penerapan UU LLAJ berkaitan denggan \\
penggunaan helm SNI sepert; kurangnya kesadaran masyarakat \\
untuk mentaati peraturan lalu lintas, dan budaya masyarakat yang \\
sudah terbiasa, apabila ingin mengendarai motor dijarak yang dekat \\
tidak menggunakan helm SNI, dan bahkan tidak menggunakan helm \\
sama sekali. Dilain pihak kurangnya personil penegak hukum untuk \\
mengawasi dan atau memantau lalu lintas di suatu daerah. Dan juga \\
kurangnya prasarana bagi pihak kepolisan mengakibatkan kesulitan \\
untuk menegakkan aturan lalu lintas yang mewajibkan \\
menggunakan helm SNI. \\
\hline Dokumentasi yang dikumpulkan oleh peneliti berupa foto \\
pengendara yang tidak taat aturan dengan tidak menggunakan helm \\
SNI, foto pihak kepolisian yang kekuarangan personil, foto sarana \\
prasarana pihak kepolisian lalu lintas yaitu pos polisi. \\
\hline
\end{tabular}

Berdasarkan matrik diatas dapat disimpulkan bahwa yang menjadi penghambat dalam menerapkan UU LLAJ, karena kurangnya kesadaran dari masyarakat, budaya masyarakat, kurangnya prasarana, dan kurangnya personil pihak kepolisian, sehingga mengakibatkan pihak kepolisian lalu lintas kesulitan mewajiban menggunakan helm SNI.

Sebagaimana yang dikemukan Soejono Soekanto (2014: 8) penegakan hukum bukan semata-mata pelaksanaan perundang-undangan saja, terdapat faktor yang mempengaruhinya yaitu;

1. Faktor hukumnya sendiri,

2. Faktor penegak hukum, yakni pihak-pihak yang membentuk maupun yang menerapkannya

3. Faktor sarana atau fasilitas yang mendukung penegakan hukum,

4. Faktor masyarakat, yakni faktor lingkungan dimana hukum tersebut berlaku atau diterapkan,

5. Faktor kebudayaan, yakni sebagai hasil karya, cipta dan rasa yang didasarkan pada karsa manusia di dalam pergumulan hidup. 
Selanjutnya beliau mengatakan bahwa; "kelima faktor tersebut saling berkaitan dengan eratnya, karena merupakan esensi dari penegakan hukum, dan juga merupakan tolak ukur daripada efektivitas penegakan hukum”. (Soerjono Soekanto, 2014: 9).

Analisis hasil temuan penelitian mengenai faktor penghambat implementasi UU LLAJ berkaitan dengan helm SNI diantaranya sebagai berikut:

1. Faktor hukum dan Undang-undang.

Sanksi yang tinggi yang akan memberi efek jera terhadap masyarakat khususnya pengendara motor tanpa ada toleransi sehingga menciptakan kepatuhan bagi masyarakat ataupun pengendara motor.

2. Kurangnya personil penegak hukum.

Pihak kepolisian masih cukup sulit untuk mengawasi ataupun memantau masyarakat khususnya pengendara motor di suatu desa-desa, dikarenakan masih kurangnya personil polisi lalu lintas di Kecamatan Tebas sehingga mengakibatkan pengendara motor tidak taat terhadap aturan lalu lintas.

3. Kurangnya sarana dan prasarana.

Polisi lalu lintas masih sangat kesulitan dikarenakan sarana dan prasarana yang tidak memadai salah satunya contohnya hanya ada satu pos polisi lalu lintas di Kecamatan Tebas saja, sedangkan di desa-desa tidak ada, hal ini sangatlah kurang untuk menegakkan aturan lalu lintas yang mewajibkan menggunakan helm SNI.

4. Kurangnya kesadaran masyarakat.

Kurangnya kesadaran masyarakat, khususnya pengendara motor yang tidak mentaati aturan lalu lintas, salah satunya masih terdapat pengendara motor yang tidak menggunakan helm SNI saat berkendara dan atau tidak sama sekali menggunakan helm, padahal aturan itu dibuat untuk memberikan keamanan dan keselamatan pengendara motor itu sendiri.

5. Budaya Masyarakat.

Budaya masyarakat yang cendrung terbiasa ataupun cendrung tidak taat pada aturan, dengan tidak menggunakan helm SNI dan atau tidak menggunakan helm pada jarak tempuh yang dekat misalnya; mau pergi ke warung, kemesjid, ke pasar, dan ke kebun.

\section{SIMPULAN}

Berdasarkan hasil penelitian yang dilakukan melalui proses wawancara dan observasi, maka dapat ditarik kesimpulan umumnya bahwa implementasi UU LLAJ yang berkaitan dengan penggunaan helm SNI di Kecamatan Tebas Kabupaten sambas, sudah berjalan dengan cukup baik,

\section{JPKN}

Jurnal Pendidikan Kewarganegaraan
Implementasi Undang-Undang Nomor 22 Tahun 2009 Tentang Lalu Lintas dan Angkutan Jalan yang Berkaitan dengan Penggunaan Helm Standar Nasional Indonesia di Kecamatan Tebas Kabupaten Sambas 
hal ini dapat ditunjukan dengan sebagian masyrakat, khususnya pengendara motor sudah memiliki kesadaran untuk mematuhi aturan berlalu lintas dengan menggunakan helm SNI. Secara khusus berdasarkan hasil penelitian dan pembahasan, maka dapat diperoleh kesimpulan bahwa; aturan UU LLAJ yang berkaiatan dengan penggunaan helm SNI di Kecmatan Tebas Kabupaten sambas sudah dilaksanakan dengan baik, hal ini ditunjukan dengan adanya aturan tentang wajib menggunakan helm SNI melalui melakukan sosialisasi, memasang pamflet dijalan bahkan apabila pengendara motor tidak menggunakan helm SNI akan di tilang dan diberikan sanksi. Sedangkan efektivitas pelaksanaan UU LLAJ yang berkaiatan dengan penggunaan helm SNI di Kecamatan Tebas Kabupaten Sambas kurang efektif, dikarenakan masyarakat yang seharusnya berperan penting dalam kelancaran, keamanan dan ketertiban, dan keselamatan berlalu-lintas, tapi pada kenyataannya justru cenderung lalai, acuh tak acuh, dan tidak mentaati tertib berlalu-lintas terutama dalam hal penggunaan helm SNI, bahkan dari data yang diperoleh pelanggaran lalu lintas tentang penggunaan helm SNI setiap tahunnya semangkin meningkat. Selanjutnya faktor penghamabat implementasi UU LLAJ berkaitan dengan penggunaan helm SNI di Kecamatan Tebas Kabupaten Sambas meliputi; faktor hukum yang tidak membuat masyarakat jera, faktor kurangnya personil dari penegak hukum untuk melakukan pengawasan, faktor kurangnya sarana dan prasarana bagi pihak kepolisian, bagaimana pihak kepolisian bekerja dengan baik apabila tidak dilengkapi dengan peralatan yang memadai ditambah lagi faktor budaya masyarakat tebas yang tidak dan atau kurang kesadaran dalam mentaati aturan.

\section{DAFTAR PUSTAKA}

Ali, Zainnudi ( 2009 ), Sosiologi Hukum. Sinar Grafika, Jakarta.

(2011), Metode Penelitian Hukum, Sinar Grafika, Jakarta.

Jimly Ashidiqqie dan M. Ali Safa'at (2012), Teori Hans Kelsen tentang Hukum, ctk. kedua, Konstitusi Press, Jakarta.

Miro, F.(2005), Perancanaan Tranportasi untuk Mahasiswa, Perencanaan dan Praktisi, Erlangga, Jakarta.

Soerjono, Soekanto (2006), Sosiologi Suatu Pengantar, Rajawali Pers, Bandung - (2014), Faktor yang Mempengaruhi Penegakan Hukum, cet.13, Rajawali Pers, Jakarta

Sugiyono (2014), Metodelogi Penelitian Pendidikan (Pendekatan Kuantitatif, Kualitatif dan $R \& D$. Alfabeta, Bandung.

Rini Septiani, Margareth Suryaningsih, Diyah Lituhayu (2013), Implementasi UU No. 22 Tahun 2009 tentang Penerapan Helm SNI di Kota Semarang, Jurnal, https//ejournal3.undip.ac.id, Journal Of Public Policy and Management Review Volume 2 Nomor 3 Tahun 2013, DOI: 10.14710/jppmr.v.2i3.3023

\section{JPKN}

Jurnal Pendidikan Kewarganegaraan
Implementasi Undang-Undang Nomor 22 Tahun 2009 Tentang Lalu Lintas dan Angkutan Jalan yang Berkaitan dengan Penggunaan Helm Standar Nasional Indonesia di Kecamatan Tebas Kabupaten Sambas 
Rahmi Illahi Waldianto (2015), Implementasi UU No. 22 Tahun 2009 (Studi Kasus : Kelancaran dan Keselamatan Lalu Lintas), Jurnal, https/ jom.unri.ac.id, jom. FISIP Volume 2 No.2 Oktober 2015.

Undang-undang Nomor 22 tahun 2009, tentang Lalu Lintas dan Angkutan Jalan https://m.liputan6.com: 30 Januari 2018, pukul 17.08 WIB 